\title{
Selected Issues of the Quality of Operation of CSM-R
}

\author{
Mirosław Siergiejczyk, Adam Rosiński \\ Warsaw University of Technology, Faculty of Transport, Department of Telecommunications in Transport, ul. Koszykowa 75, 00-662 Warsaw, Poland
}

Stanisław Gago

Railway Institute, ul. Chłopickiego 50, 04-275 Warsaw, Poland

\begin{abstract}
The article presents selected issues related to GSM-R system installed by PKP for the needs of ERTMS past-related control system, as well as the replacement of VHF analogue radio system used so far in the Polish railway system. Particular attention was given to the problems of: transition period, i.e. transition from the VHF system to the GSM-R system; proper installation of radio antennas on traction vehicles during the transition period; interfering impact of public narrowband and broadband mobile systems on the GSM-R system.
\end{abstract}

Keywords: receiver, cabin radio, GSM-R, interference, GSM

\section{Introduction}

Digital GSM-R networks are already used in many European and non-European Railway Managements. The objectives of the UIC International Union of Railways were to standardise European railway communication systems by introducing the EIRENE (European Integrated Railway radio Enhanced Network) project. GSM-R is a digital transmission system for ETCS (European Train Control System), and together they create ERTMS (European Rail Traffic Management System) $[7,8]$. In addition to data transmission for the needs of the ETCS using the EDOR (European Train Control System Data Only Radio) radio transmission, the GSM-R system assists the transmission of voice information to a driver and other railway services, which increased the role of the GSM-R system in the field of safe operation of train traffic.

The GSM-R system is based on the GSM standard and is completely compatible with it in terms of the radio interface, however, in contrast to it, it meets higher requirements in terms of service quality, both due to the fact that it is a transmission medium for the rail traffic control system in the ETCS, and it is also applied to conduct process radio communication. For these reasons, it has an impact on the train traffic operation safety.

\section{Autor korespondujący:}

Mirosław Siergiejczyk, msi@wt.pw.edu.pl

\section{Artykuł recenzowany}

nadesłany 21.05.2019 r., przyjęty do druku 27.06.2019 r.

\section{GSM-R digital railway radio communication system}

In Europe, ERTMS, namely the European Rail Traffic Management System, which includes, in addition to the GSM-R system, the European Train Control System [ETCS] that is designed to continuously collect and send data on a railway vehicle, is being implemented. The GSM-R system is a transmission medium for ETCS, it mediates the transmission of information to a driver and other railway services $[7,9,10]$. By implementing the above-mentioned systems, the rail traffic safety significantly improves and enables the real-time diagnostics of a vehicle. The immediate transfer of information on the failure detection in a train brings many benefits, i.e. it minimises the repair time, reduces the delay time, simplifies the repair process, contributes to the efficiency increase, reduces operational costs, and also allows to increase capacity on individual railway lines by a precise definition of distances between trains. It is also possible to activate the applications dedicated for passengers, e.g. information on train timetables, weather, and access to the Internet network, etc.

The equipment of the railway lines with the GSM-R system does not mean that the existing VHF radio communication system will be out of service on these lines. Analogue systems will be still available during the migration period, but they will be additionally equipped with a RCS (Remote Control System). The adopted migration concept from the VHF analogue system to the GSM-R digital system imposes additional obligations, in terms of use and maintenance of both systems, on operating services. The efficient management of such different systems requires a lot of organisational effort and good class professionals [11].

Owing to the interoperability of the GSM-R system, this system can be divided into a track side part and a train side part. The track side part includes a NSS (Network Switching 
System) subsystem, the main components of which are MSC (Mobile Switching Centre) together with the following registers:

- HLR (Home Location Register),

- VLR (Visitors Location Register),

- EIR (Equipment Identity Register),

- GCR (Group Call Register),

- and OMC (Operation Maintenance Center) and BSS (Base Subsystem).

The train side part includes a cab radio for the driver's two-way communication with the environment (train dispatchers, other drivers and other railway personnel, e.g. railway maintenance workers) and a radio for the transmission of digital signals associated with the ETCS, the so-called EDOR (ETCS Data Only Radio) [11, 13].

The EIRENE standard defines five types of mobile stations intended for the GSM-R network:

- train radiotelephone (Cab Radio) - used by the train driver),

- mobile radiotelephone for general purposes (General purpose radio),

- mobile operational radiotelephone (Operational radio),

- shunting radiotelephone (Shunting radio),

- radiotelephone for ETCS needs (EDOR).

All of these devices (except for EDOR) should operate in three frequency bands [15]:

- UIC band 876-880 / 921-925 MHz,

- GSM public band 890-915 / 935-960 MHz,

- E - GSM extended public band 880-890 / 925-935 MHz.

In the GSM-R system, it is possible to provide many telecommunications services that could not be provided in the VHF analogue radio communication system such as, for example, addressing by the message recipient's function, addressing by location, etc.

\section{GSM-R system receivers on traction vehicles}

A very important element of the train radio communication is the cab radio, which not only serves to transmit the voice between the drivers and train dispatchers, drivers and a train crew, between drivers of various trains, but it also constitutes an interface between a human (driver, train dispatcher) and train traffic operation systems (e.g. "Radiostop" and "REC" signals). The issue of the cab radio is particularly important during the migration period of the entire radio communication system, i.e. from the VHF analogue system to the GSM-R digital system and, to a large extent, it depends on the adopted migration method.

The National Implementation Plan of the European Rail Traffic Management System stipulates that in Poland, it is planned to implement the ETCS system for 5,000 km, and GSM-R for $15,000 \mathrm{~km}$ of the railway lines. The GSM-R system in the perspective of a dozen or so years is to replace the currently operated, obsolete VHF $150 \mathrm{MHz}$ analogue radio communication system. During the migration period from the analogue system to the GSM-R digital system, both systems will be operated on the railway lines. The advantage of such a solution is that: - on railway lines equipped with both radio communication systems, trains equipped with an analogue or digital radio communication system can move without any problems,

- the railway rolling stock can be successively equipped with digital devices depending on financial capabilities and the area of operation of railway carriers.

The use of two alarm signals on a single line requires the development of special procedures and rules for train traffic operation in emergency situations. The development of these procedures is particularly important for the needs of the safe train travel on the railway lines, equipped only with the GSM-R system (without the ETCS system). According to the National Implementation Plan of the European Rail Traffic Management System, the number of such railway lines in Poland is to be approx. 10,000 km.

The migration method adopted in Poland practically requires the installation of the GSM-R/VHF dual-system cab radio in the traction vehicles, which is connected with the installation of five antennas on the traction vehicles' roofs, i.e. antenna for voice service in the GSM-R system, antenna for voice service in the VHF analogue system, antenna for GPS and two antennas for digital data transmission (two radios EDOR - European Train Control System Data Only Radio). Incorrectly selected locations of these antennas on the roof of the locomotive may cause that the signals generated by these antennas will interfere with each other, which may lead to sending distorted information, e.g. to the ETCS system. Since the traction vehicles are designed in such a way that their operation is to last for several decades, it would also be necessary for newly built traction vehicles to provide space for broadband antennas, which would make, e.g. broadband Internet services available for passengers.

The correct location of antennas on the traction vehicles depends on [4]:

- the purpose of the antenna (voice transmission service, data transmission service, broadband services),

- a type of the vehicle roof (flat roof, convex roof, roof with a lowered section between cabins),

- infrastructure installed on the roof of the traction vehicle (pantographs, air conditioning, etc.).

These antennas should be located at appropriate distances on the roof of the traction vehicle so that they do not interfere with each other. There are three main mechanisms of interaction of radio waves that can cause interference problems such as blocking, undesirable emissions and intermodulation. The problems related to blocking, undesirable emissions and intermodulation can be avoided by ensuring sufficient physical isolation of antennas connected to various radio systems [6, 12]. According to the RSSB (Radio Safety Standard Board) studies, the antennas applied on the traction vehicles can be divided into three groups [3]:

- voice transmission antennas (VHF, GSM-R) and GPS,

- data transmission antennas (EDOR),

- broadband system antennas (LTE, WiMax, etc.).

In order to provide the proper isolation between the groups of these antennas, the recommended distance between them should be at least $4 \mathrm{~m}$. Figure 1 presents the risk characteristics of interference between various radio systems installed on the traction vehicles as a function of separation distances of antennas [12]. It should be assumed that small risks of interference between the above-mentioned groups of antennas occur at distances greater than $4 \mathrm{~m}$. As the distance between antennas decreases, the risk of interference increases.

Also in individual groups, individual antennas should be arranged at certain, but much smaller distances than the above-mentioned groups of antennas, e.g. VHF and GSM-R antennas for the voice transmission service should be installed at a separation distance of not less than $0.5 \mathrm{~m}$ (in this case, it is very unlikely that these two antennas will operate at the same time).

According to the English experts, the deliberations on the location of antennas on the roofs of the traction vehicles, should include a model of a simple, smooth roof with some curvatures on both sides of the traction vehicle, and this model is sufficiently accurate for many classes of the traction vehicles also located in Poland [15]. This simple type of roof allows for good multidirectional coverage from the antennas located at any place of the roof axis. Such placement of the antenna allows for good coverage at a low angle in the forward and reverse direction on a train. This is especially important for the railway communication systems, where base stations are located along the rail- 


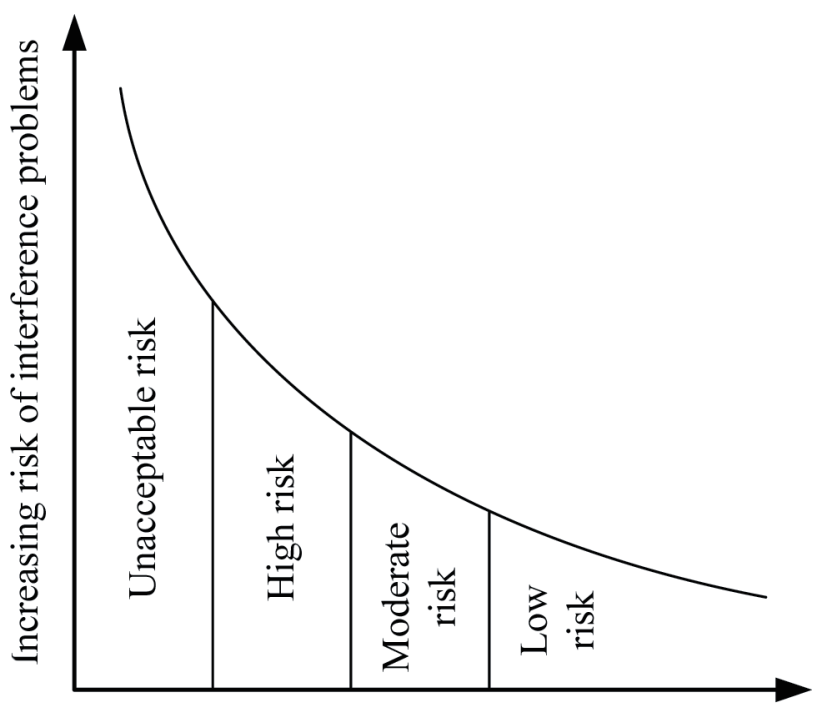

Antenna spacing proportion [\%] of recommended spacing

Fig. 1. Characteristics of the risk of interference between various radio systems installed on the traction vehicles

Rys. 1. Charakterystyka ryzyka powstania zakłóceń pomiędzy różnymi systemami radiowym zainstalowanymi na pojazdach trakcyjnych

way tracks. Unfortunately, such a situation is too idealistic. On the roofs of the traction vehicles, there are devices that introduce restrictions for a theoretical "simple model" of the traction vehicle roof. The first restriction is the gauge of the rolling stock which does not allow to place the antennas of any height on the roof of the vehicles. Therefore, in turn, special models of antennas were developed but their selection is very limited in comparison, for example, with road transport. The next restrictions are engine fans, air conditioning of cabins and passenger compartments, pantographs and other devices occupying the roof surface of the vehicle. A particularly difficult situation in terms of the placement of antennas will occur in diesel locomotives, where there is very little space on the locomotive roof. Modern traction vehicles are air-conditioned, and the assembly of air-conditioning devices is performed on the locomotive roof, which is a significant obstacle to the propagation of radio waves, especially, if the height of the antenna is lower than the height of the air-conditioning device. The ideal would be the situation that each antenna is placed higher than the "obstacles" on the roof.

The antennas on electric traction vehicles should be installed several metres away from the pantographs in order to reduce the broadband noise generated during sparking of pantographs. According to experience in other railway managements, the GPS antenna should be placed at least $5 \mathrm{~m}$ from the pantograph due to a wide spectrum of interference generated during sparking, however, other antennas should be at a distance of at least $4 \mathrm{~m}$ $[4,15]$. The raised pantograph has practically no impact on the propagation of radio waves, while the folded pantograph acts as a "metal solid" with an effect similar to the impact of the air-conditioning devices discussed above.

\section{The issue of interference of the GSM-R network receivers}

The GSM-R system is based on the GSM standard and is completely compatible with it in terms of the radio interface, however, in contrast to it, it meets higher requirements in terms of service quality, both due to the fact that it is a transmission medium for the rail traffic control system in the ETCS, and it is also applied to conduct process radio communication. For these reasons, this system has an impact on the safety of the train traffic operation.

The terminals operating in the GSM-R network meet strictly defined tasks and are assigned to specific groups of employees. The EIRENE standards define five types of terminals intended for the GSM-R network. These are [7, 10]:

- General Purpose Radio GPH (General Purpose Handheld) a general purpose mobile radiotelephone,

- Cab Radio - a train radiotelephone used by a train driver,

- Operational radio OPH (Operational Purpose Handheld) - an operational mobile radiotelephone,

- Shunting radio OPS (Operational Purpose Handheld for Shunting) - a shunting radiotelephone,

- EDOR (ETCS Data Only Radio) - a radiotelephone only for the purposes of ETCS.

The proper operation of the GSM-R system may, under certain conditions, be affected by the public GSM systems. In the general case, the interaction of the GSM-R network and the network of public operators is associated with four types of radio communication transceivers. They include:

- GSM-R network base stations,

- base stations of public networks,

- GSM-R network mobile stations,

- mobile stations of public networks.

All types of the GSM-R terminals belong to digital devices containing both a transmission part and a receiving part. The discussed issue of interference to the proper operation of terminals concerns the receiving part, as it can be subjected to strong signals from the BTS public transmitters. The two main causes of interference to the proper operation of the GSM-R system receivers include:

- undesirable emissions from public networks,

- too strong broadband signals.

As an effect of these reasons, at the receiver's input, there may occur the undesirable effects, such as:

- receiver sensitivity reduction,

- receiver blocking,

- out-of-band emissions,

- intermodulation,

- overloading of the input part of the radio system of the receiver.

\subsection{Receiver sensitivity reduction}

The reduction of the receiver sensitivity is caused by: undesirable radio emissions, intermodulation products and energy transmission of undesirable signals due to the limited selectivity of the receiver.

\subsection{Blocking of receivers caused by a high level of signals outside the GSM-R band}

The receiver blocking is defined as the maximum level of the interference signal expressed in $\mathrm{dBm}$ affecting the reduction of specific sensitivity of the receiver by the certain number of $\mathrm{dB}$ (usually $3 \mathrm{~dB}$ ). Therefore, the receiver blocking phenomenon is assessed at the level of the desired signal that is $3 \mathrm{~dB}$ higher than the receiver sensitivity level and at a frequency different from that desired signal. The receiver blocking is a measure of the receiver's capabilities of receiving the desired modulated input signals in the presence of undesirable signals at frequencies other than spurious responses or adjacent channels without reducing the receiver's performance below the acceptable limit.

The blocking and intermodulation effects of operation of the GSM-R terminals occur when the interfering radio emissions in the GSM system exceed the level of approx. $-40 \mathrm{dBm}$. It is compliant with the acceptable level of interfering signals [1], however, it is in contradiction with the acceptable power of out-of-band signals in the public band. As a result, the public 


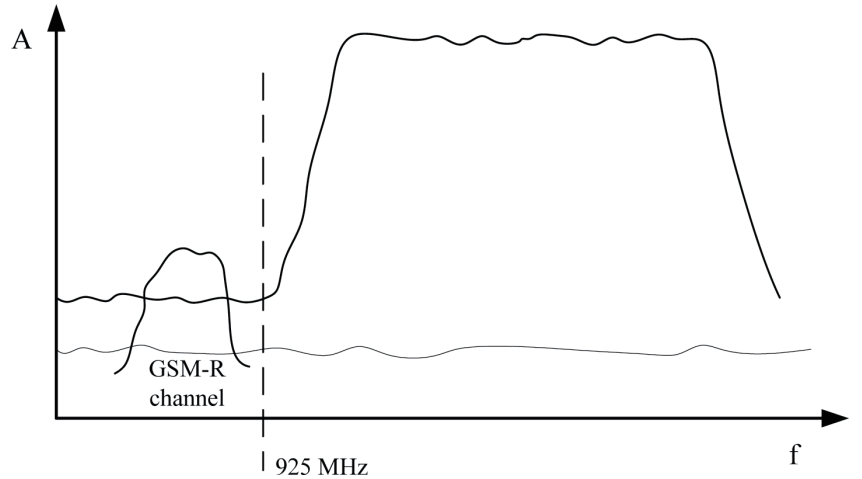

Fig. 2. Illustration of the effect of undesirable emissions from the UMTS/ LTE channel GSM-R [5]

Rys. 2. Ilustracja wpływu niepożądanych emisji z UMTS/ LTE w kanale GSM-R [5]

network receivers may introduce signals that cause interference to the operation of the GSM-R network receivers.

Out-of-band emission (OOB) occurs outside of the channel band as a result of the modulation and non-linearity process in the transmitter, without side emissions. The emissions discussed here occur at the interface of adjacent bands. Interferences occurring due to out-of-band emissions (OOB). Interferences resulting from the direct adhesion of the GSM-R network channels and the public network operator are associated with insufficient suppression of out-of-band signals. The ETSI TS 137104 [2] standard defines this phenomenon in the following way that out of band out- puts are unwanted signals coming directly from outside the channel band resulting from the modulation and non-linear processes in the transmitter, and are not undesirable emissions. Thus, if the level of out-of-band signals is insufficiently suppressed in relation to the signal strength desired, this signal will be exposed to interference (Fig. 2).

The types of interference present in the GSM-R network that occur between the GSM-R and public GSM networks are mainly dependent on the equipment of transceivers, including the following features:

- effectiveness of filtration of parasitic frequencies,

- characteristics of the propagation of radio waves of transmission antennas,

- transmitting power of transmitters,

- geographical location of base stations of interfering networks,

- the size of separation between transmission channels interfering with networks,

- levels of the network interfering signals at the ends of cells.

The most frequent impact of public networks on GSM-R results in blocking and intermodulation in the GSM-R receiving terminals. In some cases, there is also a broadband noise phenomenon. The interference was more often observed during the reception of low-power signals. As a result, the receivers have reduced sensitivity, and as a consequence, they can be overloaded and block the possibility of correct communication.

According to the recommendations set by [14] the GSM-R radio network signal level for the lines equipped with ETCS for the speed of $220 \mathrm{~km}$ (ETCS 2) cannot be lower than $-95 \mathrm{dBm}$ and for the speed of $280 \mathrm{~km} / \mathrm{h}$ lower than $-92 \mathrm{dBm}$ (ETCS 3). Therefore, in some countries (e.g. Norway, Sweden, Switzerland), in order to guarantee a proper difference in signals between the GSM-R network and the public operators' networks, it was assumed that the levels of signals from the GSM network narrowband transmitters cannot exceed the level of $-107 \mathrm{dBm} / 200 \mathrm{kHz}$ in the railway areas. In case of the UMTS and LTE broadband networks, it was adopted that the signal level for the first frequency block adjacent to the GSM-R band should not be transmit- ted with power exceeding the value of $-33 \mathrm{dBm} / 5 \mathrm{MHz}$, and in subsequent channels, it should not exceed $-23 \mathrm{dBm} / 5 \mathrm{MHz}[13]$.

\section{Conclusion}

The article discusses the mobile on-board part of the GSM-R system in the field of radiotelecommunications services on drivers as well as the rules of the placement of the radio system antennas installed on the traction vehicles. The considerations were limited to radiotelecommunications services which will be most often used by the railway vehicle drivers and to the selected rules for installation of antennas in the traction vehicles that have a direct impact on the transmitted information quality (e.g. only physical separation of antennas was discussed and a method for using appropriate filters was omitted).

The authors believe that the appropriate rules of, e.g. installation of antennas should be developed in Poland for each type of the traction vehicle and its "roof" equipment, on which the appropriate antenna types will be installed for the provision of specific radiotelecommunications services. For example, it is currently possible to apply multi-band antennas as well as frequency multiplexers that allow to reduce the number of antennas and perhaps may allow to reduce the antenna separation distances. The adopted quality of services (QoS) for individual telecommunications services is also important, e.g. there is different quality for the voice transmission service, and the different one for the data transmission service (EDOR). The data transmission quality will have a decisive impact on the separation distances of antennas.

The interruption of radio communication used in the railway rolling stock has a huge impact on the train traffic and the safety of passengers and service providers. The continuous availability and accessibility to the GSM-R network is needed to transmit and receive alarm signals (Railway Emergency Call) along the entire railway line. In addition, depending on the railway operational needs, critical zones can be identified at the national level, in the places such as:

- places where trains start or continue their travel after stopping,

- places where dangerous situations may occur,

- areas with ETCS level 2/3, where continuous data transmission is required:

- limit zones of ETCS Level 2/3,

- places where a handover occurs.

The GSM-R digital rail radio communication system belongs to important elements affecting the technological process course in the railway transport. The direct adherence of the GSM-R system operation band and the transmission band of public operators promotes the creation of interference, the effects of which have a direct influence on the operation of the GSM-R system receivers. The work carried out at CEPT and ETSI resulted in the creation of a series of guidelines aimed at weakening the impact of adverse effects on the GSM-R receivers. Among them, it is indicated to improve the filtration of the receiver's input stages and the use of improved GSM-R modems. Subsequently, it is proposed to reduce the power of transmitters of public operators emitting the radio signals towards the railway areas, and to reorganise the frequency in the band directly adjacent to the GSM-R band.

\section{References}

1. ETCS/GSM-R Quality of Service - Operational Analysis, European Economic Interest Group- European Rail Traffic Management System. Reference EEIG: 04E117 Distribution date: $14 / 10 / 05$. 
2. ETSI TS 137 104. Technical Specification Digital cellular telecommunications system (Phase 2+); Universal Mobile Telecommunications System (UMTS); LTE; E-UTRA, UTRA and GSM/EDGE; Multi-Standard Radio (MSR) Base Station (BS) radio transmission and recep-tion (3GPP TS 37.104 version 9.1.0 Release 9). April 2010.

3. GSM-R Radio, Guidance on GSM-R Cell Planning Consultation, 12-2007, Association of Train Operating Companies.

4. Guidance on Train Rooftop Antenna Positioning, Rail Industry Guidance Note Document comes into force 04/12/2010. Published by RSSB.

5. Hasenpusch T., Compatibility measurements UMTS/LTE/ GSM vs GSM-R.pdf http://www.era.europa.eu.

6. Katulski R.J., Propagacja fal radiowych w telekomunikacji bezprzewodowej [Propagation of radio waves in wireless telecommunications]. Wydawnictwo WKiE [Transport and Communication Publishers], Warsaw 2010.

7. Monografia [Monograph]. Koleje dużych prędkości w Polsce [High speed railways in Poland]. Redakcja naukowa M. Siergiejczyk. [Scientific editor: M. Siergiejczyk] Oficyna Wydawnicza Politechniki Warszawskiej [Publishing House of Warsaw University of Technology]. Warsaw 2015.

8. Pawlik M., Siergiejczyk M., Gago S., Safety of the new control command European System, in: Safety and Reliability: Methodology and Applications. Nowakowski T. [et al.] (Ed.), 2015, CRC Press/Taylor \& Francis Group/Balkema.

9. Praca statutowa WT PW. [Statutory work of Faculty of Transport of Warsaw University of Technology]. Analiza i ocena własności eksploatacyjnych systemów telematyki transportu [Analysis and assessment of the operating properties of transport telematics systems]. Praca statutowa Zakład Telekomunikacji w Transporcie, 2017 [Statutory work of the Department of Telecommunications in Transport, 2017]. Kierownik pracy M. Siergiejczyk [Work manager M. Siergiejczyk].

10. Siergiejczyk M., Gago S., Safety and security, availability and certification of the GSM-R network for ETCS purposes. "Archives of Transport System Telematics", Vol. 7, Issue 1, 2014, 45-49.

11. Siergiejczyk M., Gago S., Zagadnienia eksploatacji systemów radiołaczności kolejowej w okresie migracji. Logistyka $4 / 2014$ [The isues of operation of the rail radio communication systems during migration Logistics 4/2014].

12. Sumiła M., Miszkiewicz A., Analysis of the problem of interference of the public network operators to GSM-R. International Conference on Transport Systems Telematics TST 2015. Tools of Transport Telematics. Spinger 2015. 253-263.

13. UIC FREQUENCY MANAGEMENT WORKING GROUP. Assessment report on GSM-R current and future radio environment. July 2014.

14. UIC Project EIRENE. System Requirements Specification, GSM-R Operators Group, System Requirements Specification (SRS) Version 16.0.0. December 2015.

15. Williams D.J.S., Train Roof Antenna Positioning Issues Study, End-of-Study Report Research Programme Engineering Rail Safety and Standards Board LTD, 25/08/2009.

\section{Streszczenie: W artykule przedstawiono wybrane problemy związane z instalowanym przez PKP systemem GSM-R dla potrzeb przeszłościowego systemu sterowania ERTMS a także zastąpienia radiowego systemu analogowego VHF stosowanego do tej pory w polskim kolejnictwie. Szczególną uwagę poświęcono problemom: okresu przejściowego tj. przejścia z systemu VHF do systemu GSM-R, odpowiedniej instalacji anten radiowych na pojazdach trakcyjnych w okresie przejściowym, zakłócającego wpływu publicznych systemów komórkowych wąsko- i szerokopasmowych na system GSM-R.}

Słowa kluczowe: odbiornik, radio kabinowe, GSM-R, zakłócenia, GSM 
Associate Prof. Miroslaw Siergiejczyk, PhD. Eng. msi@wt.pw.edu.pl

Scientific fields of interest of the paper co-author concern among other issues of architecture and services provided by telecommunications networks and systems, especially from perspective of their applications in transport, reliability and operation of telecommunications networks and systems, modelling, designing and organising telecommunications systems for transport.

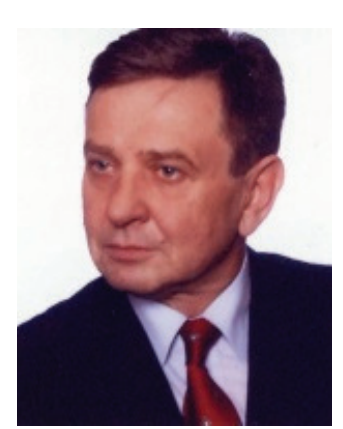

\section{Stanisław Gago, PhD. Eng.}

\section{s.gago@wp.pl}

Scientific fields of interest of the paper co-author concern among other issues of architecture and services provided by telecommunications networks and systems, especially from perspective of their applications in rail transport.

\section{Associate Prof. Adam Rosiński, PhD. Eng.}

\author{
adro@wt.pw.edu.p
}

Research interests include Intelligent Transportation Systems, electronics (analog and digital) and issues related to reliability, exploitation, diagnostics and design of electronic security systems (intrusion detection, video surveillance systems, access control systems, fire alarm systems, voice evacuation systems, monitoring systems, systems integration), with special regard to their use in transport. He has aca-

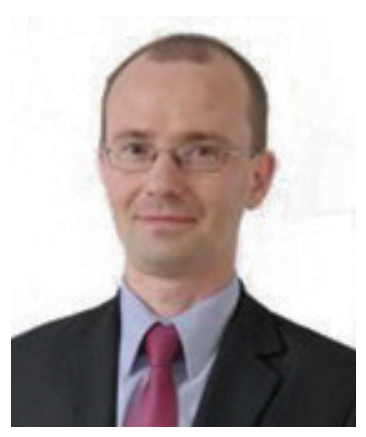
demic achievements (as author or co-author) six books and over 100 articles, and many unique solutions in the field of security of a special nature. Member of the Traffic Control Team in the Road Transport of the Traffic Control Section in the Transport Committee of the Polish Academy of Sciences in the 2016-2020 term. Member of the Polish Scientific and Technical Exploitation Society. 